\title{
Impact of Crude Protein Intake in Last 14 Days of Pregnancy on Puerperium, Piglet Loss Prior to Weaning and Subsequent Reproduction of Sows
}

\author{
D. TYDLITÁT ${ }^{1}$, A. VINKLER ${ }^{2}$, L. CZANDERLOVÁ $^{1}$ \\ ${ }^{1}$ Sevaron Consulting, 1td., Brno, Czech Republic \\ ${ }^{2}$ Clinic of Pig Diseases, Faculty of Veterinary Medicine, \\ University of Veterinary and Pharmaceutical Sciences Brno, Czech Republic
}

Received February 14, 2007

Accepted October 2, 2007

\begin{abstract}
Tydlitát D., A. Vinkler, L. Czanderlová: Impact of Crude Protein Intake in Last 14 Days of Pregnancy on Puerperium, Piglet Loss Prior to Weaning and Subsequent Reproduction of Sows. Acta Vet. Brno 2007, 76:585-593.

The impact of feed containing $13 \%, 15 \%, 18 \%$ and $21 \%$ of crude protein fed to groups of sows (marked A, B, C and D) from Day 100 of pregnancy until farrowing on puerperium, piglet loss prior weaning, fat depot differences, onset of reproductive activities after weaning, subsequent mating and the progesterone concentrations were studied. In groups A and B there were no puerperium disorders. Piglet loss before weaning reached 16.12 and $18.04 \%$ of all born piglets, $90 \%$ of sows became pregnant after the $1^{\text {st }}$ insemination. In groups $C$ and D the overall loss of all born piglets before weaning was 24.86 and $28.91 \%$. The differences to groups A and B were significant $(p<0.05)$. Significant differences $(p<0.05)$ were found between groups A, B and C, D in number of animals exceeding body temperature of $39.6{ }^{\circ} \mathrm{C}$. Puerperium disorders and MMA syndrome were detected in $50 \%$ of the sows in group $\mathrm{C}$ and $80 \%$ in group $\mathrm{D}$. The conception rate after the $1^{\text {st }}$ insemination was $80 \%$ (group C) and $60 \%$ (group D). Reduction in the back fat thickness was at the boundary of statistical significance $(p<0.1)$ in groups $\mathrm{C}$ and $\mathrm{D}$ as compared to groups $\mathrm{A}$ and $\mathrm{B}$. There was no difference in the onset of heat after weaning between the groups. In progesterone concentrations, significant differences $(p<0.05)$ were found between groups A and D on Day 14 after weaning. We demonstrated a negative impact of high crude protein intake in last 14 days of pregnancy in sows on puerperium and piglet loss prior to weaning.
\end{abstract}

Pig, nutrition, body temperature, MMA syndrome, weaning, conception, progesterone

In the last two weeks prior to farrowing, foetuses increase their farrowing weight almost by $40 \%$ and they gain energy sources depots that are vitally important in order to survive before the first colostrum intake. Therefore, the sow needs more protein and energy in this period of rapid foetal growth. If the sow, however, does not ingest the necessary nutrient in feed in this period, she mobilises her own fat depots and breaks down protein in order to cover the needs of the developing foetuses. The sow, however, turns catabolic already before farrowing and this situation negatively influences the sow's optimum milk production (Boyd 1999; Doležel and Kudláč 2000).

The sow's milk production can be disrupted by the development of the MMA (mastitis, metritis, agalactia) syndrome. The body temperature of the sow after delivery ranges around $39.2{ }^{\circ} \mathrm{C}$. Temperature measurements at least twice a day $3-5$ days after the delivery are important for the assessment of the overall health status of the sow. Temperature above $39.5^{\circ} \mathrm{C}$ is always a signal for searching for the cause of fever and its treatment (Kozumplík and Kudlác 1980). The most common cause of the MMA syndrome from the nutrition point of view is high raw protein intake (Sandstedt and Sjorgen 1982). A lower agalactia incidence was found in sows with low energy intake in the period of late pregnancy (Goransson 1989). Increased energy intake from Day 75 till Day 105 of pregnancy did not benefit mammary development (Weldon et al. 1991).

An increase in feed consumption during lactation has no impact on milk production but it

Address for correspondence:

MVDr. David Tydlitat

Sevaron, ltd.

Palackeho 163a, 62100 Brno

Czech Republic

Phone: +420541426373

E-mail: david@sevaron.cz

http://www.vfu.cz/acta-vet/actavet.htm 
significantly influences the sow's health status (Pluske et al. 1998). A reduction in feed intake during lactation results in a weight loss and overall physical condition deterioration. A major loss of weight during lactation causes a prolongation of service interval, it reduces the number of sows in which oestrus starts within ten days after weaning, the conception index and it increases embryonic loss (Aherne and Williams 1992). Sows with delayed heat after weaning have a lower conception index and the litter size in the subsequent farrowing is reduced.

The hormonal profile of the sow changes after farrowing. The progesterone concentration, which dominates in the course of pregnancy, decreases only a few days before delivery. After farrowing, it decreases even more. Low oestrogen and progesterone during the puerperium reflect low activity of the ovaries during this period (Kudláč 1988).

In sows, lactation and piglet weaning have a strong influence on the ovarian activity and indirectly also on the changes in the reproduction organs during puerperium. A return to a fully functioning reproductive cycle and to ovulation does not usually take place before the weaning of the piglets. Tubbs (1990) mentions the optimum lactation period as 3 - 4 weeks with regard to an optimal number of piglets per sow per year.

A fully functioning reproductive cycle starts approximately within one week of the weaning (Svajgr et al. 1974); Čech (2000) specifies it between Day 5 and 8, Kudláč (2005) within ten days, with the highest frequency between Day 4 and 7 after weaning, and Vinkler and Zajíc (2005) between Days 3 and 10 after weaning. It can be generally said that the later the weaning, the sooner after weaning the next oestrus occurs, i.e., the shorter the service period (interval between weaning and the onset of next oestrus) (Svajgr et al. 1974). The interval between farrowing and the first ovulation can be reduced by a temporary separation of all piglets from the dam for a varied amount of time in the day or by permanent weaning of a section of the litter (Britt 1986).

Nutrition plays an important role in the gestation period. Although in a majority of sows fed a diet containing normal amount of energy during gestation, oestrus started within seven days after weaning, only slightly less than $30 \%$ of sows fed an energy-rich diet during pregnancy came in heat within seven days after weaning (Xue et al. 1997). Inadequate nutrition and significant weight loss can result in a delayed onset of cyclic ovarian activity (Britt et al. 1985). The presence of a boar may have the opposite result (Kudláč 1988).

The aim of the experiment was to assess the impact of protein contents in the feed of sows in the last 14 days of pregnancy (i.e. from Day 100 of pregnancy) on the postdelivery period, the onset of reproductive activity after weaning, changes in progesterone concentrations after weaning, piglet loss prior weaning, changes of the health status in connection with back fat thickness, mating results and the assessment of the numbers of still births and live births in piglets and their farrowing weights in subsequent litters.

\section{Materials and Methods}

Monitoring was done at a farm with 1000 sows, crossbreeds of the Czech Improved White and the Czech Landrace. The herd was vaccinated against porcine parvovirosis. The experiments were performed at the end of March and beginning of April 2004. Sows aged between 1.5 and 3 years were included in the experiments (in their $2^{\text {nd }}$ to $5^{\text {th }}$ pregnancies - the proportion of parities was the same within all groups), transferred into the farrowing house between Day 94 and 100 of pregnancy. Starting with their transfer into the farrowing house, the sows were fed different feed rations. The nutritional values of the feeding mixtures were obtained by calculation.

Group A sows $(\mathrm{n}=27)$ were fed a full feed mixture for farrowing sows from their transfer into the farrowing house. The feed mixture was compounded of $70 \%$ barley corn, $5 \%$ wheat corn, $17 \%$ wheat bran, $5 \%$ soy-extracted groats and 3\% feed mineral supplement. It contained $134.24 \mathrm{~g}$ of nitrogenous substances per $\mathrm{kg}$ and $11.87 \mathrm{MJ} / \mathrm{kg}$ of pig metabolizable energy. Daily intake in the period from the transfer into the farrowing house until delivery was $335.6 \mathrm{~g}$ of crude protein and $29.68 \mathrm{MJ}$ of metabolisable energy.

Group B sows $(n=53)$ were fed a full feed mixture for lactating sows from the transfer into the farrowing house. The feed mixture consisted of $46 \%$ barley corn, $35 \%$ wheat corn, $3 \%$ wheat bran, $9.5 \%$ soy-extracted groats, $3.5 \%$ rape-extracted groats and 3\% feed mineral supplement. It contained $158.21 \mathrm{~g}$ of nitrogenous substances per $\mathrm{kg}$ and $12.54 \mathrm{MJ} / \mathrm{kg}$ of pig metabolisable energy. Daily intake of crude protein in the period from the transfer into the farrowing house until delivery was $395.5 \mathrm{~g}$ and daily intake of metabolisable energy was $31.35 \mathrm{MJ}$. 
Group C sows $(n=10)$ were fed a feed mixture that was compounded of $12 \%$ barley corn, $33 \%$ wheat corn, $17 \%$ maize, $11 \%$ soy-extracted groats, $8 \%$ soy oil, $11 \%$ thermally treated soy, $5 \%$ rape pressings and $3 \%$ feed mineral supplement. It contained $179.31 \mathrm{~g}$ of nitrogenous substances per $\mathrm{kg}$ and $15.36 \mathrm{MJ} / \mathrm{kg}$ of pig metabolisable energy from the transfer into the farrowing house. Daily intake of crude protein in the period from the transfer into the farrowing house until delivery was $448.3 \mathrm{~g}$ and daily intake of metabolisable energy was $38.40 \mathrm{MJ}$.

Group D sows $(n=10)$ were fed a feed mixture that consisted of $29 \%$ wheat corn, $8 \%$ maize, $5 \%$ soy-extracted groats, $15 \%$ soy oil, $23 \%$ thermally treated soy, $5 \%$ rape pressings, $12 \%$ fish meal and $3 \%$ feed mineral supplement. It contained $210.04 \mathrm{~g}$ of nitrogenous substances per $\mathrm{kg}$ and $17.52 \mathrm{MJ} / \mathrm{kg}$ of pig metabolisable energy from the transfer into the farrowing house. Daily intake of crude protein in the period from the transfer into the farrowing house until delivery was $525.1 \mathrm{~g}$. Daily intake of metabolisable energy was $43.80 \mathrm{MJ}$.

The ration size of the feed mixtures was identical in both groups. After the transfer into the farrowing house, it was $2.5 \mathrm{~kg}$ of feed mixture daily. On the day of farrowing, no feed was offered and after delivery the sows were fed ad libitum feed mixture for lactating sows containing $158.2 \mathrm{~g}$ of nitrogenous substances per $\mathrm{kg}$ of feed mixture and $12.54 \mathrm{MJ} / \mathrm{kg}$ of metabolisable energy.

In all animals the numbers of live born, stillborn, died and weaned piglets were recorded. In ten randomly selected sows from groups $\mathrm{A}$ and $\mathrm{B}$ and in all sows in groups $\mathrm{C}$ and $\mathrm{D}$, the rectal temperatures were taken on the day of delivery and in the following five days always between 10:00 and 11:00 h. Twenty thermometers were read at the same moment in water at a temperature around $38^{\circ} \mathrm{C}$. A set of 6 thermometers that showed the values nearest to the average of 20 thermometers tested was selected for measuring the rectal temperature. In the same animals daily changes were recorded in the period of the puerperium, based on discharge from the reproductive organs, changes in the mammary gland, in piglet behaviour and the piglet loss rate in the individual sows into special protocols. The back fat thickness $\left(\mathrm{P}_{2}\right)$ was determined on the day of the transfer into the farrowing house and at weaning with an ultrasound Draminski Animal Scanner with a $5 \mathrm{MHz}$ probe (manufacturer Draminski Electronics in Agriculture, Poland). After weaning the piglets, the onset of the heat in sows was monitored using a back-pressure test in the presence of a boar and all sows were inseminated with the semen of the same boars by the same staff. After 18 - 22 days, the sows were monitored for the onset of the following heat and inseminated again upon its detection. At the following deliveries after the experiment, the total and still birth counts were kept, as well as their delivery weights.

For progesterone analysis after weaning, blood from the v. jugularis was collected using a HEMOS 03 sampling set. It was then left to settle at room temperature in order to enable coagulation. The serum was then removed by suction, centrifuged and after the sediment removal, it was refrigerated. On completion of all blood samplings, the progesterone concentrations were determined using ELISA (enzyme-linked immunosorbent assay) by Immunolab, Germany.

The data were processed statistically using a $t$-test for independent samples.

\section{Results}

\section{Rectal temperatures during and after farrowing}

In group A, two sows displayed a temperature of $39.5^{\circ} \mathrm{C}$ and one $39.6^{\circ} \mathrm{C}$. In group $\mathrm{B}$, the temperature of $39.5^{\circ} \mathrm{C}$ was found in one sow. In group $\mathrm{C}$, the temperature ranged between $39.6-40.0{ }^{\circ} \mathrm{C}$ in three sows and three animals had a temperature higher than $40.0{ }^{\circ} \mathrm{C}$. In group $\mathrm{D}$, the temperature of $39.6-40.0^{\circ} \mathrm{C}$ was found in two sows and a temperature higher than $40.0{ }^{\circ} \mathrm{C}$ in four animals. In groups $\mathrm{A}$ and $\mathrm{B}$, always a one-day rise in temperature occurred, on the other hand, in groups $\mathrm{C}$ and $\mathrm{D}$ it was a several-day rise. Average body temperatures were higher in groups $\mathrm{C}$ and D. Significant differences were not confirmed among the body temperature values in groups A, B, C and D. As to the sow numbers with a temperature higher than $39.6^{\circ} \mathrm{C}$, significant differences $(p<0.05)$ were found between groups $\mathrm{A}, \mathrm{B}$ and $\mathrm{C}, \mathrm{D}$, respectively.

\section{Post-delivery complications}

In groups $\mathrm{A}$ and $\mathrm{B}$, no symptoms pointing to the MMA syndrome were detected. In group C, MMA syndrome symptoms occurred in five animals $(50 \%)$ and in group D in eight animals $(80 \%)$. The differences between the values of the MMA syndrome incidence in groups $\mathrm{C}$ and $\mathrm{D}$ are significant $(p<0.05)$, as opposed to the groups $\mathrm{A}$ and $\mathrm{B}$.

\section{Piglet loss prior to weaning}

Table 1 reports piglet loss that occurred in the course of nursing. In Table 2, piglet loss data include still-births as well.

Mortality differences in groups $\mathrm{C}$ and $\mathrm{D}$ compared to groups $\mathrm{A}$ and $\mathrm{B}$ were at the 
Table 1. Average number of live born and weaned piglets and mortality rate percentage of suckling piglets at varied levels of crude protein in the feed

\begin{tabular}{|c|c|c|c|c|c|c|c|}
\hline \multirow{2}{*}{ Group } & \multirow{2}{*}{$\begin{array}{l}\text { Number } \\
\text { of sows }\end{array}$} & \multicolumn{2}{|c|}{$\begin{array}{c}\text { Number } \\
\text { of live born }\end{array}$} & \multicolumn{2}{c|}{$\begin{array}{c}\text { Number of } \\
\text { weaned }\end{array}$} & \multicolumn{2}{c|}{ Died } \\
\cline { 3 - 8 } & & Average & SD & Average* & SD & Animals & $\%$ Mortality* \\
\hline A & 27 & 9.39 & 3.62 & 8.64 & 2.86 & 0.75 & 7.99 \\
\hline B & 53 & 9.06 & 2.54 & 8.36 & 2.16 & 0.70 & 7.73 \\
\hline C & 10 & 8.80 & 2.01 & 7.89 & 2.52 & 0.91 & 10.34 \\
\hline D & 10 & 8.10 & 2.85 & 7.18 & 2.29 & 0.92 & 11.36 \\
\hline
\end{tabular}

* A : C, $p<0.1, \mathrm{~A}: \mathrm{D}, p<0.1, \mathrm{~B}: \mathrm{C}, p<0.1, \mathrm{~B}: \mathrm{D}, p<0.1$

Table 2. Average numbers of all born and weaned piglets and loss percentage of suckling piglets at varied levels of crude protein in the feed

\begin{tabular}{|c|c|c|c|c|c|c|c|}
\hline \multirow{2}{*}{ Group } & \multirow{2}{*}{$\begin{array}{c}\text { Number } \\
\text { of sows }\end{array}$} & \multicolumn{2}{|c|}{$\begin{array}{c}\text { Number } \\
\text { of all born }\end{array}$} & \multicolumn{2}{c|}{$\begin{array}{c}\text { Number of } \\
\text { weaned }\end{array}$} & \multicolumn{3}{c|}{ Total loss } \\
\cline { 3 - 8 } & & Average & SD & Average & SD & Animals & $\%$ loss* \\
\hline A & 27 & 10.30 & 3.86 & 8.64 & 2.86 & 1.66 & 16.12 \\
\hline B & 53 & 10.20 & 2.81 & 8.36 & 2.16 & 1.84 & 18.04 \\
\hline C & 10 & 10.50 & 2.09 & 7.89 & 2.52 & 2.61 & 24.86 \\
\hline D & 10 & 10.10 & 1.54 & 7.18 & 2.29 & 2.92 & 28.91 \\
\hline
\end{tabular}

* A : C, $p<0.05, \mathrm{~A}: \mathrm{D}, p<0.05, \mathrm{~B}: \mathrm{C}, p<0.05, \mathrm{~B}: \mathrm{D}, p<0.05$

borderline of statistical significance $(p<0.1)$. Differences in the weaned piglet numbers in groups $\mathrm{C}$ and $\mathrm{D}$ in comparison to groups $\mathrm{A}$ and $\mathrm{B}$ are at the borderline of statistical significance $(p<0.1)$.

Differences in loss rates (the difference between the total of piglets born and the weaned piglet total) were statistically significant $(p<0.05)$ in groups $\mathrm{C}$ and $\mathrm{D}$ as compared to A and $\mathrm{B}$.

Back fat thickness $\left(\mathrm{P}_{2}\right)$

The difference in the back fat thickness between Day 100 of pregnancy and the day of weaning was the highest in group A $(-5.7 \mathrm{~mm})$ and the lowest in group D $(-0.1 \mathrm{~mm})$ (Fig. 1). The differences in back fat thickness reduction in groups $\mathrm{C}$ and $\mathrm{D}$ as compared to groups A and B were at the borderline of statistical significance $(\mathrm{p}<0.1)$.

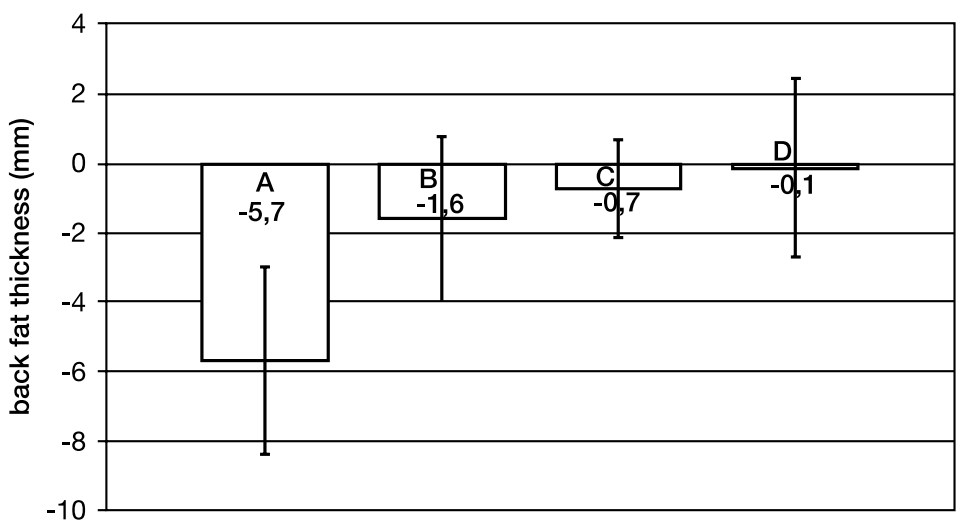

Fig. 1. Average reduction of the back fat thickness in the given period (mm) 
The onset of oestral activity after weaning and mating results

The interval between weaning and the onset of heat was 5.7 days in group A, 5.8 days in group B, 6.1 days in group C and 6.2 days in group D. Heat started in all monitored sows in groups A, B, C and D. Differences in the heat onset lengths after weaning were not significant.

In groups $\mathrm{A}$ and $\mathrm{B}$, nine sows $(90 \%)$ became pregnant after the first insemination and one sow was removed. In group C, eight sows $(80 \%)$ became pregnant after the first insemination, one sow $(10 \%)$ became pregnant after the second insemination and one animal was removed. In group D, six sows $(60 \%)$ became pregnant after the first insemination, two animals (20\%) after the second insemination and two sows were removed.

\section{Progesterone concentrations}

Progesterone concentrations were determined on Days 7, 14 and 21 after weaning (Fig. 2). The average progesterone concentrations in the blood of sows were $1.1 \mathrm{ng} / \mathrm{ml}$ in group A on Day 7 after weaning, $16.3 \mathrm{ng} / \mathrm{ml}$ on Day 14 after weaning and $17.3 \mathrm{ng} / \mathrm{ml}$ on Day 21 after weaning; $1.0 \mathrm{ng} / \mathrm{ml}$ in group B were on Day 7 after weaning, $12.5 \mathrm{ng} / \mathrm{ml}$ on Day 14 after weaning and $9.6 \mathrm{ng} / \mathrm{ml}$ on Day 21 after weaning. In group C, the values were found of $0.9 \mathrm{ng} / \mathrm{ml}$ on Day 7 after weaning, $10.2 \mathrm{ng} / \mathrm{ml}$ on Day 14 after weaning and 10.1 $\mathrm{ng} / \mathrm{ml}$ on Day 21 after weaning. In group D, the progesterone concentrations were $0.6 \mathrm{ng} / \mathrm{ml}$ on Day 7 after weaning, $9.5 \mathrm{ng} / \mathrm{ml}$ on Day 14 after weaning and $9.5 \mathrm{ng} / \mathrm{ml}$ on Day 21 after weaning. When comparing groups A, B, C and D on Days 7, 14 and 21 after weaning, the differences in progesterone concentrations were at the borderline of statistical significance $(p<0.1)$. Between groups A and D, the difference in progesterone concentrations was significant $(p<0.05)$ on Day 14 after weaning.

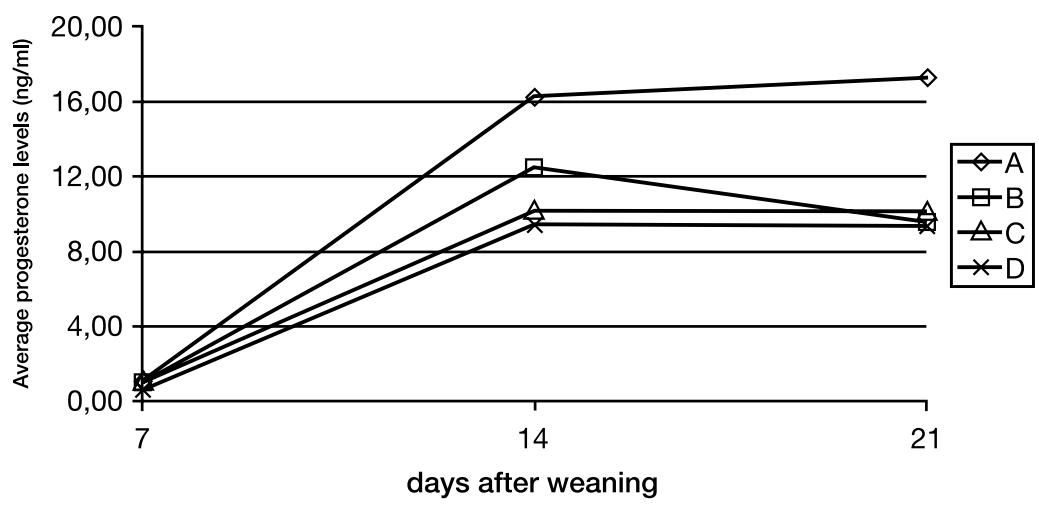

Fig. 2. Average progesterone concentrations in sows after weaning

Total piglet counts, live birth counts and the average farrowing weights of piglets in the subsequent delivery

In litters that followed after the completion of the study, litter size, live birth piglets and the average farrowing weights of piglets were recorded. In group A, the litter size was 9.6 piglets, 10.1 piglets in group $\mathrm{B}, 9.2$ piglets in group $\mathrm{C}$ and 10.0 piglets in group $\mathrm{D}$. Live born piglet numbers were 8.6 piglets in group A, 8.8 piglets in group B, 8.1 piglets in 8.5 piglets group $\mathrm{C}$ and in group $\mathrm{D}$.

The average farrowing weights were $1.5 \mathrm{~kg}$ in group A, $1.5 \mathrm{~kg}$ in group B, $1.5 \mathrm{~kg}$ in group $C$ and $1.5 \mathrm{~kg}$ in group D. There were no significant differences between groups A, B, $\mathrm{C}$ and $\mathrm{D}$ in the values of litter size, live birth counts and the average farrowing weights of piglets in the subsequent deliveries. 


\section{Discussion}

The body temperature of the sows on delivery matched literature data (Kozumplík and Kudláč 1980). In the period after farrowing, the situation differed. In groups A and B with lower contents of crude protein (13 and 15\%) in the diet, there was an increase in body temperatures to $39.5^{\circ} \mathrm{C}$ in three cases and in one case up to $39.6^{\circ} \mathrm{C}$ but they were only oneday increases. In groups $\mathrm{C}$ and $\mathrm{D}$ with higher contents of crude protein (18 and $21 \%$ ), the situation was significantly worse. In both these groups, an increase in body temperatures above $39.6{ }^{\circ} \mathrm{C}$ occurred in six out of ten animals, while in three sows in group $\mathrm{C}$ and in four sows in group D, there was an increase over $40.0^{\circ} \mathrm{C}$. This situation lasted for a longer period of time and it required medical treatment.

In five sows from group $\mathrm{C}$ and eight sows from groups $\mathrm{D}$, the MMA syndrome was diagnosed which is a significantly higher number of affected sows than in groups A and $B$, of which no sow was diagnosed with the MMA syndrome. The numbers of sows with the MMA syndrome in groups $\mathrm{C}$ and $\mathrm{D}$ do not correspond to the total numbers of sows in these groups, where temperature exceeded $39.6^{\circ} \mathrm{C}$. Of six sows with a body temperature over $39.6^{\circ} \mathrm{C}$ in group $\mathrm{C}$, only five were diagnosed with the MMA syndrome. In group $\mathrm{D}$, the MMA syndrome diagnosis was confirmed in eight sows, and only in six cases the temperature was higher than $39.6^{\circ} \mathrm{C}$. A series of factors may cause the MMA syndrome (Doležel and Kudláč 2000). Sandstedt and Sjorgen (1982) see an interrelation between higher feed protein intake and the incidence of the MMA syndrome. There is an agreement between our results and these conclusions as to the development of the MMA syndrome.

The mortality rate of piglets in the lactation period was $7.99 \%$ in group A, and $7.73 \%$ in group B. Mortality rate increased to $10.34 \%$ in group C, and to $11.36 \%$ in group D. The differences in mortality rates in groups $\mathrm{C}$ and $\mathrm{D}$ as compared to groups $\mathrm{A}$ and $\mathrm{B}$ were at the borderline of statistical significance $(p<0.1)$. According to Matoušek and Kernerová (2005) and Čeřovský (2005), the farrowing house loss should not exceed $10 \%$. Groups C and D exceed this limit only slightly. This lower extent of mortality was especially due to good hygienic conditions in the farrowing house. Similarly, good hygienic conditions prevented the mortality of piglets in the lactation period in group $\mathrm{C}$ and $\mathrm{D}$ sows as compared to those in groups A and B; it was higher. This could have been an effect of the MMA syndrome, whose higher incidence was significant in groups C and D together with interrelated lower milk production of the sows in the first days after farrowing. With respect to the fact that the thorough monitoring of the sows enabled the detection of the onset of the MMA syndrome and its timely treatment, the total piglet loss in the nursing period was relatively low.

The total piglet loss during farrowing to the period prior weaning is based on the stillbirth number and loss during lactation. In groups A, the total loss was $16.12 \%$ of all born piglets, $18.04 \%$ in group B, as high as $24.86 \%$ in group $\mathrm{C}$ and the total loss of all born piglets was $28.91 \%$ in group D. The losses in groups C and D are significant $(p<0.05)$ compared to groups A and B. The high concentrations of these variables in groups $\mathrm{C}$ and $\mathrm{D}$ are especially due to the high still-birth count. An increase in crude protein in the feed from Day 100 of pregnancy thus significantly reduced the numbers of weaned piglets per sow and the apparent good results in the loss rate in the lactation period mask the total loss rate that bordered on $30 \%$ in group D.

In the back fat thickness alterations during lactation, there were differences between the groups of sows. The biggest reduction by $5.7 \mathrm{~mm}$ occurred in group A, by $1.6 \mathrm{~mm}$ in group B, by $0.7 \mathrm{~mm}$ in group C $0.7 \mathrm{~mm}$ and the smallest reduction by $0.1 \mathrm{~mm}$ occurred in group $\mathrm{D}$. The differences in values between groups $\mathrm{A}, \mathrm{B}$ and $\mathrm{C}, \mathrm{D}$ were at the borderline of statistical significance. The trend of reducing the loss in back fat during lactation in connection with increased crude protein and energy intake matches literature data (Aherne 
and Williams 1992). These changes did not exercise influence on the onset of heat after weaning.

In all monitored sows of all groups, heat started after weaning. At the time of the onset of heat after weaning, there was no significant difference between sows of groups A, B, C and D. This interval ranged between Day 5.7 and 6.2, which matches literature data (Svajgr et al. 1974; Čech 2000; Kudláč 2005).

Poorer results in the mating rate after the first insemination in groups $\mathrm{C}$ and $\mathrm{D}$ can be interrelated with complications during puerperium because the incidence of puerperal complications with detected MMA syndrome symptoms occurred in groups with increased protein intake before farrowing, while in sows with lower protein contents in feed (groups A and B), these symptoms were not detected. Also the relatively later, though not significantly, onset of heat after weaning in groups $\mathrm{C}$ and $\mathrm{D}$ could exercise certain influence on the mating results. The progesterone concentrations after weaning can be to a certain degree connected with these results as well. They were lower in sows with higher concentrations of crude protein in feed in the last 14 days of pregnancy. Even though the differences in progesterone concentrations on Day 7 after weaning are at the borderline of statistical significance, they point to the fact that heat in the first two groups started earlier and was shorter. Different progesterone concentrations on Day 14 after weaning can then bring evidence of differences in the numbers of developing corpora lutea in the given groups of sows and thus also in the numbers of ovulating follicles. Lower progesterone concentrations can indicate that the higher ratio of crude protein in groups C and D in the time before delivery had impact not only on the course of the puerperium and involution of the uterus but possibly also on the stabilisation of the hypothalamus, hypophysis, ovarian axis. The detected progesterone concentrations on Day 14 after weaning (i.e. Day 7 to 9 after heat and insemination) indicate in part of the sows of groups $\mathrm{C}$ and $\mathrm{D}$ that the first heat after weaning could have been related to the lower number of ovulations and impaired function of the corpus luteum. This also corresponds to the lower rate of mating after first insemination, detected mainly in group D. The removed sows were inseminated in the following heat. The overall rate of mating after the first and the second inseminations did not vary significantly between groups. The quality of the second heat was already sufficient since in the subsequent farrowings, there was no significant difference in the numbers of all and live born piglets or in their farrowing weights between groups A, B, C and D, that were in the subsequent pregnancies fed in the same manner as group B.

In conclusion, while monitoring the impact of feed containing 13\% (group A), 15\% (group B), 18\% (group C) and 21\% (group D) of crude protein from Day 100 of pregnancy of the sows until farrowing, the following was found:

1. The total loss of all born piglets prior to weaning was increased by the higher crude protein intake in last 14 days of pregnancy: from $16.12 \%$ in group A to $18.04 \%$ and $24.86 \%$ in groups $\mathrm{B}$ and $\mathrm{C}$ and up to $28.91 \%$ in group $\mathrm{D}$. The difference between groups $\mathrm{A}$ and $\mathrm{B}$ was non-significant, the difference between groups $\mathrm{C}$ and $\mathrm{D}$ on one part and groups $\mathrm{A}$ and $\mathrm{B}$ on the other was significant $(p<0.05)$.

2. The higher crude protein intake in the last 14 days of pregnancy increased significantly the numbers of sows that had rectal temperatures in the range of $39.5^{\circ} \mathrm{C}-40.0^{\circ} \mathrm{C}$ during 5 days after delivery and sows that had temperatures above $40.0{ }^{\circ} \mathrm{C}$ during 5 days after farrowing were in groups $\mathrm{C}$ and $\mathrm{D}$ compared to groups $\mathrm{A}$ and $\mathrm{B}$.

3. The incidence of clinical signs of the MMA syndrome was increased by the higher crude protein intake in last 14 days of pregnancy: $0 \%$ sows in group A, $0 \%$ sows in group $\mathrm{B}, 50 \%$ sows in group $\mathrm{C}$ and $80 \%$ sows in group $\mathrm{D}$.

4. The back fat thickness reduction from Day 100 of pregnancy prior to weaning was $5.7 \mathrm{~mm}$ in group A, $1.6 \mathrm{~mm}$ in group $\mathrm{B}, 0.7 \mathrm{~mm}$ in group C and $0.1 \mathrm{~mm}$ in group D. These differences were at the borderline of statistical significance. 
5. The progesterone concentrations in blood serum of the sows 7,14 and 21 days after weaning displayed differences at the borderline of statistical significance while a trend in reducing the progesterone concentrations coinciding with the increasing content of crude protein in feed was detected from Day 100 of pregnancy until farrowing. The difference between progesterone concentrations 14 days after weaning between the group A and D was significant $(p<0.05)$.

6. In all groups, heat started approximately from Day 5.7 (group A) to Day 6.2 (group D). There were no significant differences between the groups in the time of the onset of heat after weaning.

7. After the first insemination, $90 \%$ sows became pregnant in group A and B, $80 \%$ in group $\mathrm{C}$ and $60 \%$ in group $\mathrm{D}$ of the inseminated sows.

8. There were no significant differences in the numbers of all and live born piglets in the subsequent deliveries and in their farrowing weights between the individual groups.

\section{Vliv př́ijmu dusíkatých látek v posledních 14 dnech březosti na puerperium, ztráty selat do odstavu a následnou reprodukci prasnic}

Byl sledován vliv krmiva s obsahem $13 \%, 15 \%, 18 \%$ a $21 \%$ dusíkatých látek zkrmovaného skupinám prasnic (označeným A, B, C a D) od 100. dne březosti do porodu na puerperium, ztráty selat do odstavu, změny tukových rezerv, nástup pohlavní aktivity po odstavu, následné zabřezávání a koncentrace progesteronu. Ve skupinách $\mathrm{A}$ a $\mathrm{B}$ nebylo zjištěno žádné narušení puerperia. Ztráty selat do odstavu dosahovaly 16.12 a $18.04 \%$ ze všech narozených, $90 \%$ prasnic zabřezlo po 1 . inseminaci. Ve skupinách C a D dosáhla ztráta ze všech narozených selat do odstavu 24.86 a $28.91 \%$. Rozdíly vůči skupinám A a B byly statisticky významné $(p<0.05)$. Statisticky významné rozdíly $(p<0.05)$ byly nalezeny mezi skupinami $\mathrm{A}, \mathrm{B}$ a $\mathrm{C}, \mathrm{D}$ v počtech zvírat překračujících tělesnou teplotu $39.6{ }^{\circ} \mathrm{C}$. Narušení puerperia a MMA syndrom byl zjištěn u $50 \%$ prasnic ve skupině C a $80 \%$ ve skupině D. Míra zabřezávání po 1 . inseminaci byla $80 \%$ (skupina C) a $60 \%$ (skupina D). Míra snížení hřbetního tuku byla na hranici statistické významnosti v porovnání skupin A a B ke skupinám C a D. Mezi skupinami nebyl žádný rozdíl v nástupu ř́je po odstavu. U hladin progesteronu byl nalezen statisticky významný rozdíl mezi skupinami A a D 14. den po odstavu. Byl prokázán negativní dopad vysokého př́imu dusíkatých látek v posledních 14 dnech březosti prasnic na puerperium a ztráty selat do odstavu.

\section{Acknowledgement}

This study was performed with the support received from the Research Project No. VZ MSM 6215712403.

\section{References}

AHERNE FX, WILLIAMS IH 1992: Nutrition for optimizing breeding herd performance. Vet Clin North Am Food Anim Pract 8: 589-608

BOYD J 1999: A three diet strategy for the lifetime feeding of gilts and sows. In: PENNY RHC, MACHIN DH: Pig reproduction: problems, practices and principles. Cambac Associates publications, pp. 51-62

BRITT JH 1986: Improving sow productivity through management during gestation, lactation and after weaning. J Anim Sci 63: 1288-1296

BRITT JH, ARMSTRONG JD, COX NM, ESBENSHADE KL 1985: Control of follicular development during and after lactation in sows. J Reprod Fertil 33(Suppl): 37-54

ČECH S 2000: Parturition in sow. In: DOLEŽEL R, KUDLÁČ E: Veterinary obstetrics. University of Veterinary and Pharmaceutical Sciences Brno, Brno, $43 \mathrm{p}$.

ČEŘOVSKÝ J 2005: Reproduction of pigs. In: PULKRÁBEK J, ČEŘOVSKÝ J, DOLEJŠ J, DRÁBEK J, DUBANSKÝV, HÁJEK J, KERNEROVÁ N, KVAPILÍK J, MATOUŠEK V, NOVÁK P, PRAŽÁK Č, PYTLOUN J, ROZKOT M, ŠPINKA M, TOUFAR O, VALIŠ L, ZEMAN L: Breeding of pigs. Profi Press, Prague, pp. 55-67

DOLEŽEL R, KUDLÁČ E 2000: Veterinary obstetrics. University of Veterinary and Pharmaceutical Sciences Brno, Brno, 193 p. 
GORANSSON L 1989: The effect of dietary crude fibre content on the frequency of post partum agalactia in the sows. J Vet Med A 36: 474-479

KOZUMPLÍK J, KUDLÁČ E 1980: Reproduction of pigs in factory farming. SZN, Prague, 296 p.

KUDLÁČ E 1988: Physiology and pathology of puerperium and influence of reproductive function in postnatal period in cows and sows. Dissertation. University of Veterinary and Pharmaceutical Sciences Brno, Brno, 205 p.

KUDLÁČ E 2005: Biological and breeding aspects of successful reproduction of pigs. In: Proceesings of CPVS Conference Reproduction of pigs III. on 8. 4. 2005 in Hradec Králové. CPVS, Brno, pp. 25-27

MATOUŠEK V, KERNEROVÁ N 2005: Tvarové a užitkové vlastnosti prasat. In: PULKRÁBEK J, ČEŘOVSKÝ J, DOLEJŠ J, DRÁBEK J, DUBANSKÝ V, HÁJEK J, KERNEROVÁ N, KVAPILÍK J, MATOUŠEK V, NOVÁK P, PRAŽÁK Č, PYTLOUN J, ROZKOT M, ŠPINKA M, TOUFAR O, VALIŠ, L, ZEMAN L Breeding of pigs. Profi Press, Prague, pp. 23-34

PLUSKE JR, WILLIAMS IH, ZAK LJ, CLOWES EJ, CEGIELSKI AC, AHERNE FX 1998: Feeding lactating primiparous sows to establish three divergent metabolite states: III. Milk production and pig growth. J Anim Sci 76: $1165-1171$

SANDSTEDT H, SJORGEN U 1982: Preventive measures against a high prevalence of mastitis-metritis-agalactia syndrome in sows. Sv Vet Tidn 34: 487-490

SVAJGR AL, HAYS VW, CROMWELL GL, DUTT RH 1974: Effect of lactation duration on reproductive performance of sows. J Anim Sci 38: 100-105

TUBBS RC 1990: Factors that influence the weaning-to-estrus interval in sows. Comp Cont Educ Pract Vet 12: 105-115

VINKLER A, ZAJÍC J 2005: Monitoring of reproductive activity of gilts and sows. In: Proceesings of CPVS Conference Reproduction of pigs III on 8. 4. 2005 in Hradec Králové. CPVS, Brno, pp. 23-27

WELDON WC, THULIN AJ, MACDOUGALD OA, JOHNSTON LJ, MILLER ER, TUCKER HA 1991: Effects of increased dietary energy and protein during late gestation on mammary development in gilts. J Anim Sci 69: $194-200$

XUE JL, KOKETSU Y, DIAL GD, PETTIGREW J, SOWER A 1997: Glucose tolerance, luteinizing hormone release, and reproductive performance of first-litter sows fed two concentrations of energy during gestation. J Anim Sci 75: 1845-1852 
